MARIA STRENACIKOVA SR. MARIA STRENACIKOVA JR.

Academy of Arts

Banska Bystrica, Slovakia

ORCID: 0000-0002-7087-9730

maria.strenacikova@aku.sk

ORCID: 0000-0001-5555-0091

maria.strenacikova1@aku.sk
МАРИЯ СТРЕНАЧИКОВА, СТ. МАРИЯ СТРЕНАЧИКОВА, МЛ.

Академия искусств

2. Банска-Бистрища, Словакия

ORCID: 0000-0002-7087-9730

maria.strenacikova@aku.sk

ORCID: 0000-0001-5555-0091

maria.strenacikova1@aku.sk

\section{Slovak music culture and music professions during Classicism era}

The Classicist period in Slovakia developed between 1760 and 1830. At that time Slovakia was a part of the territory of the Hungary. Musical culture during the reign of Maria Theresa, Joseph II and Francis I evolved in three stages under the influence of the European musical tradition and contacts with foreign composers from Austria, Germany and Czechia. People could listen to all sorts of music in opera houses, concert halls, noblemen's courts, petty bourgeois salons and in the countryside. Musical professions in Slovakia were comparable with those in Central Europe. Musicians' jobs included those of performers, composers, teachers, writers, theoreticians and organizers of cultural life. Usually, one person held two or more of these positions. Composers wrote works which were performed at various occasions. Music teachers taught at state-run music schools, pedagogical colleges and parochial schools. Manufacturers of musical instruments created a number of new instruments, especially wind instruments, violins and organs, many of which were regarded as being highly significant throughout Europe.

\section{Словацкая музыкальная культура и музыкальные профессии в период классицизма}

Период классицизма в Словакии развивался с 1760 по 1830 год. В то время Словакия была частью территории Венгрии. Во времена правления Марии Терезии, Иосифа II и Франциска I музыкальная культура развивалась в три этапа под влиянием европейской музыкальной традиции и контактов с иностранными композиторами из Австрии, Германии и Чехии. Музыка звучала везде: в опере, концертных залах, при дворцах, в мещанских салонах и в сельской местности. Музыкальные профессии в Словакии были сопоставимы с профессиями в Центральной Европе. К музыкантам относились исполнители, композиторы, учителя, писатели, теоретики и организаторы культурной жизни. Один человек обычно занимал одну или несколько из этих должностей. Композиторы создавали произведения, которые исполнялись в различных ситуациях. Учителя музыки преподавали в государственной музыкальной школе, педагогическом училище, церковнодуховных школах. Создатели музыкальных инструментов сконструировали ряд новых инструментов, особенно духовых, скрипок и орга́нов, многие из которых достигли европейского значения. 
Keywords:

Classicism, music, culture, profession, Slovakia.
Ключевые слова:

классицизм, музыка, культура, профессия, Словакия.

For citation/Для цитирования:

Maria Strenacikova Sr., Maria Strenacikova Jr. Slovak Music Culture and Music Professions During Classicism Era // ICONI. 2021. No. 1, pp. 68-74. DOI: 10.33779/2658-4824.2021.1.068-074.

\section{Introduction}

$\mathrm{D}$ uring Slovak Classicism, between 1760 and 1830, present-day Slovakia was part of the northern Hungarian Empire (Kingdom of Hungary), known as Captaincy of Upper Hungary. The population of German, Slovak, Hungarian and Croatian nationalities, and a large part of the Hungarian nobility, scientists, artists and merchants lived and operated here. The territory was divided into districts, which had a greater maturity, level and power, the closer they were to Bratislava and Vienna [5].

The greatest primetime, the "golden age", is associated with the reign of Maria Theresa. The capital was Bratislava, where the central authorities housed, regional assemblies were convened, and important political and power struggles between the centralist efforts of Vienna court and the interests of the Hungarian nobility took place. The successor of Maria Theresa, Joseph II, continued with the reforms, but in 1784 he annulled Bratislava's privileges as the capital and political center. He assigned them to Buda, and therefore Bratislava lost its prestigious position. However, the process of social and economic changes in Slovakia was already unstoppable and inevitable, and it resulted in the multifaceted changes in the society [3]. The system was shifting from the feudal to the capitalist and the intellectual and the philosophical movements that the Enlightenment brought, causing fundamental changes in the cultural life of Slovakia as well.

\section{Music culture in Slovakia}

In our interpretation, the term music culture includes all components that contribute to the existence of music in a particular period.

The music culture of Classicism was created and influenced by:

- music composers (leading personalities, authors of smaller and minor importance),

- performers of music (professional musicians, amateurs, folk musicians),

- compositional creation (works / compositions),

- music cultivation (in churches, monasteries, palaces, town theaters, bourgeois households),

- music education (church - religious education, public schools, private classes),

- instrument workrooms (production and improvement of musical instruments),

- publishers and printers (music sheet, books, journals and magazines),

- music contacts with foreign countries (traveling composers, performers, teachers shared works).

The individual components were never in balance. Some dominated, others developed to a lesser extent, or temporarily stagnated.

In Classicism, fundamental changes in musical development occurred. They were a consequence of progressive democratization and secularization. However, the process of change was not straightforward - it moved from aristocratic circles to the bourgeoisie environment, and from church to secular music. Public music schools were 
established, concert life was opened to the public, domestic music making spread, and music attachments in magazines were published.

Musical life flourished in operas, concert halls, residences, and in bourgeois salons. The nobility paid ensembles and the best musicians to perform for them.

Secular music was played, well-known works by important Austrian, German and Czech composers; mainly works by J. Haydn, W. A. Mozart and L. van Beethoven were performed. An important center of music culture was the Grassalkovich Palace in Bratislava, which was built in the years 1756-1760.

Sacral music and works in the Baroque style continued to predominate in the countryside. Rich musical life was happening in religious monasteries, temples and in bourgeois houses [7].

Rural musical folklore was also popular: folk performers were often called to aristocratic residences because of their lower financial cost. Famous folk festivities were the popular dance parties in Košice, with music from popular folk ensembles. Thanks to their excellent level of interpretation, these were able to perform in any environment - from simple village pubs to aristocratic salons.

Music also sounded in aristocratic families on an amateur level, since the nobles themselves (musical amateurs) ordered songs that they were able to play on a lay level [1]. A rarity was the amateur music and theater activities of the employees of the Forestry Office and school youth in Liptovský Hrádok. A report on a shepherd's play has been preserved, which evidenced that the employees themselves created both music and lyrics for the play.

\section{Music professions during Classicism}

Music professions were comparable with those in the central European environment. Musicians worked as interpreters, composers, teachers, writers, theoreticians and organizers of cultural life, while combining two or more of these posts. Their social status was tied to the economic situation [7]. In contemporary practice the composer was also a teacher or a theorist; the performer participated in the organization of musical life, the teacher also worked as an organist; the theorist was active in journalism and composition, etc.

Slovak music composers wrote a number of compositions, many of which fulfilled the aesthetic ideal of Classicism. Popular pieces included sonatas, rondos, variations, fantasies, songs, quartets, etc. Over time, the Classical composers began to belong to one of the three categories, according to the importance and quality of their works. Important composers wrote works that bear the hallmarks of advanced Classicism and had a reach and influence beyond the Hungarian Kingdom. Composers of regional significance composed pieces, which had features of the region or the nation. Thirdly, works by composers of local significance sounded only in a narrow audience circles, and features of composing craft prevailed over their artistic skills.

Music teachers taught in various towns. However, the most prestigious institutions were in Bratislava, Košice and Spišská Kapitula. In Bratislava, the music education class was established and it became the first public music school. Since it was considered one of the best in Hungary, it achieved the status of a "model school", so called "Musterschule". In Košice, schools focused on the education of cantors and organists who performed throughout eastern Slovakia. There was a pedagogical school in Spišská Kapitula and another successful special class of music education and instrumental music in Trenčín. Education flourished at an excellent level in religious orders, among which the Piarists (Trenčín), the Jesuits (Košice, Trnava) and the Ursulines (Bratislava, Pieštany) excelled [10].

One of the most famous teachers was Franz Paul Rigler, a composer and piano virtuoso who lived in Bratislava. He was responsible for music in the school reform, 
Ratio educationis. He is also the author of the textbook, the piano school "Anleitung zum Klavier”, which has long been used in Europe [2].

Musical instruments manufacturers also played an important role. Even though instrumental workrooms were spread throughout Slovakia, several of them had reached only a local level without a wider impact. The best quality instruments, those with a European reputation, were crafted in violin, organ and wind instrument workrooms.

Wind instruments from Slovakia were widely recognized and sought after. European musicians ordered improved basset horns by Theodor Lotz and improved French horns by Engelbert Lansmann from Bratislava. Karol Schmidt introduced his own claveolin, similar to harmonium (reed organ), and produced popular and sought-after keyboard instruments such as clavichords and pianos. In Spiš, these instruments were produced with success and recognition by the Wallachy family from Spišská Sobota and by Jakub Roth and Jozef Schmidt from Vrbov [8].

Relatively little is known about the production of percussion instruments, as they have been preserved in very limited quantities. For example, of all 4,000 specimens of instruments in the Music Museum in Bratislava, only 16 are idiophones and even only 10 are membranophones. Most records come from Spiš and Šariš: their military function, use on ceremonial secular occasions and in sacred music are described. The specific names of the manufacturers or workshops are not known, since percussion instruments were neither signed, nor marked with names or signs [11].

Violin production flourished in the second half of the 18th century in Bratislava, where both excellent violinists and string instrument manufacturers lived and worked. They came from Vienna, the Czech Republic and Germany; they settled in the town to supply the high need for more and more instruments for a numerous body of musicians, and quickly set up family workrooms. Later, their sons and students worked in these. They provided high-quality instruments to aristocratic ensembles, church ensembles and monasteries. The first violinmaker was Anton Thir I, who settled in Bratislava around 1750 after arriving from Vienna. His masterpieces were highly valued and very popular. His sons Ondrej and Anton Thir II, followed Thir's art. They used maple and spruce wood, and tirelessly experimented with lacquer coatings, which gradually changed from a completely dark color to bright red-chestnut and red-gold-brown shades. Equally important violinmakers came from the Leeb family: Ján Juraj Leeb I, Ján Juraj Leeb II, Ján Juraj Leeb III, Ondrej Karol Leeb. Their instruments were beautifully shaped, elaborated and polished with a rich palette of colors from brown through shades of dark red-brown to yellow. The Leebs became famous as the best, most progressive Hungarian violin producers. They raised many successors, including Ondrej Thir, who was a pupil of J. J. Leeb III. After the death of J. J. Leeb III, his workshop was taken over by Jozef Hamberger Sr., who was the founder of another important violinmaker family. At that time, they had competition only in the successful and productive violin workroom of the Ertlovs. Besides Bratislava, other workrooms had a very good reputation: the Trnava workroom of Ján Pavel Wörle, the Nitra violin-maker room of František Kerkovič, the Košice workroom of Ján Juraj Leeb I., and the Prešov violinproducing workroom of Adam Molnár. The Slovak school for manufacturing violin was originally based on instrument models by A. Steiner, N. Amati and A. Stradivari. During its 150-year flourishing period, it developed its typical Slovak characteristic features. [6] High importance was acknowledged also to the organ manufacturers in Slovakia. Organs crafted in the famous family Pažický from Rajec sounded in churches in Slovakia, Poland, Silesia and Lower Hungary. During 120 years, the Pažický family built more than 200 instruments. The founder of the 
workroom was Ján Pažický, who allegedly worked as a mill journeyman and was a selftaught organist. Several organs are preserved in churches and are still used today, many of them have only the cabinet preserved, or their instrumental part has been electrified or replaced. Other masterpieces were built by the father and son Podkonický from Banská Bystrica. It is not known how father Martin entered the organ making craft, but he was a sought-after expert who always did precise and professional work, as evidenced by the organs in Levoča, Žaškov, Smrečany and Špania Dolina. His son Michal, after the return from his studies in Jena, Germany, continued in the organ making tradition and after his father's death, he fully took over the family workroom. He obtained orders from all over Hungary and built organs of extraordinary beauty, unique size and rare sound qualities [4].

Special music professions included activities of music theoreticians. In Classicism, the theory of music reflected the practical requirements of musical life. It was not purposeless, because theoretical thinking was characterized by a specific connection between theoretical and practical aspects. In relation to practice, music theory visibly and fully manifested itself in three areas, in music pedagogy, in the instrument making craft and in music journalism. The pedagogical area was focused on teaching musical instrument playing, teaching singing, improving the general-bass technique and acquiring basic theoretical knowledge and skills in practical composition procedures. The theory was a part of published schools for musical instruments and of song collections, and it had an instructive mission. Besides the previously mentioned textbook Anleitung zum Klavier by Franz Paul Rigler, a collection of spiritual songs Melodiatura or Partytura by Adam Škultéty was published in Brno (in the year of the Buda edition of Rigler's representative work, in 1798). The author wrote it in a very understandable form: in the theoretical part he used a simple intelligible language and he tried to create a Slovak musical terminology. The author tried to get as close to rural organists as possible. He did not create a scientific musictheoretical work, but a practical guide for amateurs. The level of his work was payable to the purpose for which it was created [12]. He defined the basic concepts necessary for the creation of a general bass song accompaniment. For example:

- A tact was a "arty time division into certain equal particles."

- He called preludes ante-playings and pointed out that "...they should not be offensive, too long here and there runnings on the organ...”.

- He recognized three types of tones: “... $a$ proper tone that has no marks, a hard tone, marked with a sharp sign and a soft or sad tone, fore-signatured by letter $b$. ." $[13,20]$

Overall, it can be stated that Slovak music theory in Classicism significantly lagged behind the level of the composition and interpretation sphere.

\section{Publishers and printing companies}

The great expansion of technology, inventions and scientific discoveries typical of the Enlightenment of the 18th Century, significantly and positively marked all areas of life. The music culture was mainly influenced by the new quality of the typography and the improvement of music printing. In Slovakia, the modern type of printers spread rapidly, and almost all major towns could be proud of their own printers and publishers. Although Vienna had a monopoly position in the monarchy, the peak significance was attributed to the Printing Center in Bratislava, the Košice Jesuit Printing House and the Trnava University Printing House. The printers also actively and progressively worked in Banská Bystrica, Prešov, Skalica, Banská Štiavnica and Komárno. Their outcomes included compositions by domestic authors, editions of Haydn's, Mozart's works, many compositions by other foreign authors, opera librettos, popular and sought-after music attachments 
of journals and magazines. Also, the titles of unnotated but music related literature were published (e.g. the Pressburger Zeitung newspaper regularly reported on music news and music activities, and in Hungary, the most widely read periodicals were multiple editions of cancionales, concert programs, lyrics, etc.) [9].

\section{Summary}

Music Classicism in Slovakia was evolving similarly to that in Central Europe. It was influenced by the philosophy of that time, the political situation and economic conditions. Many changes were characteristic for music culture, including a shift from church music to secular music and from aristocratic environment to the bourgeoisie. Musical life developed in opera houses, concert halls, residences, etc. In addition to church music in churches and in the countryside, secular music associated with the names of important Austrian and German composers (the wellknown trio Haydn, Mozart, Beethoven) was developing. In the countryside, the people also enjoyed the folk music.

Composers, performers, teachers, but also writers, often combining several posts, dominated the music professions. Manufacturers of musical instruments, especially the wind instruments (improved French horns and Basset horns), organs and violins were of the greatest importance on a European level. In music theory, two basic works were created: Anleitung zum klavier by Franz Paul Rigler, and Melodiatura or Partytura by Adam Škultéty. The publishing houses and printers of notes, sheet music appendices, lyrics, etc. also played an important role in the development of music culture in Classicism.

\section{e REFERENCES}

1. Bokesová Z. et al. Dejiny slovenskej hudby [A History of Slovak Music]. Bratislava: Vydavatel'stvo SAV, 1957, 540 p.

2. Burlas L. Dejiny európskej hudobnej teórie [A History of European Music Theory]. Žilina: Žilinská univerzita, 2007, $134 \mathrm{p}$.

3. Elschek O. (ed.) Dejiny hudby na Slovensku [A History of Music in Slovakia]. Bratislava: SAV, 1996. $572 \mathrm{p}$.

4. Gergely O. \& Wurm, K. Historické organy na Slovensku [Historical Organs in Slovakia]. Bratislava: OPUS, 1982. $351 \mathrm{p}$.

5. Kolektív: Ottova encyklopédia SLOVENSKO A - Ž [Otto’s Encyclopedia SLOVAKIA A - Z]. Bratislava: Ottovo nakladatel'stvo, 2006. 1056 p.

6. Kresák M. Husliarske umenie na Slovensku [The Art of Violin Playing in Slovakia]. Bratislava: Tatran, 1984. $264 \mathrm{p}$.

7. Múdra D. Dejiny hudobnej kultúry na Slovensku II. Klasicizmus [A History of Music Culture in Slovakia. II. Classicism]. Bratislava SHV, 1993. 316 p.

8. Múdra D. Hudobný klasicizmus na Slovensku v dobových dokumentoch [Musical Classicism in Slovakia in the Documents of the Period]. Bratislava: Ister Science, 1996. 279 p.

9. Pad'our R. Dejiny kníhtlače v Žiline [The History of Typography]. Brno: Masarykova univerzita. Manuscript. 2013. 37 p. (in Slovak)

10. Starosta M. Kapitoly z dejín klavírneho umenia a pedagogiky klavírnej hry [Chapters from the History of Piano Art and Piano Pedagogy]. Bratislava: VŠMU, 2000.132 p.

11. Strenáčiková M. Sr. \& Strenáčiková, M. Jr. Dejiny hudobnej kultúry na Slovensku. 3. Klasicizmus. [A History of the Musical Culture in Slovakia. 3. Classicism]. Manuscript. 150 p.

12. Škraban T. Evanjelická duchovná hudba ako súčast života krestáanov [Evangelical Spiritual Music as a Part of the Life of Christians]. Banská Bystrica: Pedagogická fakulta UMB. Manuscript. 2012. $148 \mathrm{p}$.

13. Zúriková-Predmerská A. K výročiam Adama Škultétyho a jeho Melodyarury aneb Partytury. [Concerning the Anniversaries of Adam Škultéty and his Melodicism in his Musical Scores]. Cirkevné listy [Church Letters], CXXXII/12, 2008, pp. 18-22. 
About the authors:

Maria Strenacikova Sr., Doc. Mgr. Art., C.Sc., Faculty of Music Arts, Academy of Arts (97401, Banska Bystrica, Slovakia),

ORCID: 0000-0002-7087-9730, maria.strenacikova@aku.sk

Maria Strenacikova Jr., PaedDr., Ph.D., Faculty of Music Arts, Academy of Arts (97401, Banska Bystrica, Slovakia),

ORCID: 0000-0001-5555-0091, maria.strenacikova1@aku.sk

Об авторах:

Стреначикова Мария ст., магистр искусств, кандидат наук, доцент кафедры теоретических предметов факультета музыкального искусства, Академия искусств (97401, г. Банска-Бистрица, Словакия), ORCID: 0000-0002-7087-9730, maria.strenacikova@aku.sk

Стреначикова Мария мл., доктор педагогических наук, кандидат наук, преподаватель кафедры теоретических предметов факультета музыкального искусства, Академия искусств (97401, г. Банска-Бистрица, Словакия),

ORCID: 0000-0001-5555-0091, maria.strenacikova1@aku.sk 